\title{
STRATEGI PROMOSI ABOVE THE LINE PRODUK MINUMAN ROOT BEER - THE GROOVY TASTE® DI WILAYAH JABODETABEK (2010-2011)
}

\author{
Melina Sari \\ Program Studi S2 Magister Manajemen Eksekutif Muda \\ Sekolah Tinggi Manajemen PPM \\ Pepey Riawati Kurnia \\ Sekolah Tinggi Manajemen PPM
}

\begin{abstract}
Tujuan studi ini adalah untuk merumuskan strategi promosi above the line untuk Root Beer - The Groovy Taste ${ }^{\circledR}$, yang merupakan produk minuman carbonated soft drink. Studi ini menggunakan penelitian eksploratori untuk mengetahui kondisi eksternal dan industri, serta menggunakan penelitian deskriptif untuk mengetahui perilaku konsumen dari industri carbonated soft drink. Dalam formulasi strategi promosi akan ditentukan target audience, tujuan komunikasi, sasaran yang akan dicapai oleh strategi promosi ini, anggaran, desain komunikasi dan bauran media. Implementasi strategi promosi dibuat dalam bentuk Media Plan, yang berisi jadwal implementasi berikut anggaran promosi yang dibutuhkan.
\end{abstract}

Keywords:

Strategi promosi, above the line promotion, carbonated soft drink 


\section{PENDAHULUAN}

\subsection{Latar Belakang}

Berdasarkan hasil penelitian Zenith International Global Soft Drink (www. zenithinternational.com), jumlah volume soft drink yang diminum secara global di tahun 2004 mencapai 467 miliar liter dengan ratarata 75 liter/orang dan pada tahun 2008 jumlahnya meningkat mencapai 552 miliar liter dengan rata-rata 82,5 liter/orang. Soft drink yang paling banyak diminum adalah carbonated soft drink dengan pangsa pasar sebanyak $46,8 \%$ pada tahun 2004 , meningkat menjadi 53,1\% di tahun 2008.

Di Indonesia sendiri pada tahun 2009 jumlah pangsa pasar untuk soft drink diprediksi mencapai Rp 9,444 trilyun, dimana carbonated soft drink menduduki peringkat pertama dengan pangsa pasar sebesar 21\% atau sekitar Rp 2 trilyun.

PT KMI (bukan nama sebenarnya) adalah sebuah perusahaan yang bergerak di bidang produksi dan distribusi soft drink. Saat ini jenis soft drink yang sudah diproduksi oleh PT KMI adalah carbonated soft drink, yaitu: Root Beer, Cruzz, Navika, RC Cola dan Zoda. Produk unggulan PT KMI adalah Root Beer - The Groovy Taste ${ }^{\circledR}$, dimana kuantitas penjualannya mencapai $72 \%$ dari seluruh penjualan produk carbonated soft drink.

\subsection{Rumusan Masalah}

a. Hasil evaluasi manajemen pada tahun pertama terhadap produk Root Beer The Groovy Taste ${ }^{\circledR}$, tidak menunjukkan kinerja yang memenuhi target/anggaran penjualan dan laba yang telah ditetapkan oleh perusahaan. Perusahaan menargetkan periode pengembalian investasi di tahun ke-5, namun berdasarkan proyeksi dari kinerja tahun 2009 didapatkan bahwa sampai dengan tahun ke-5 cash profit perusahaan masih akan minus.

b. Rendahnya brand awareness Root Beer - The Groovy Taste ${ }^{\circledR}$. Berdasarkan hasil survei awal (Januari 2010) yang dilakukan kepada 60 orang responden diperoleh hasil: 16,6\% responden yang menjawab tahu dan mampu mengidentifikasi produk Root Beer - The Groovy Taste ${ }^{\circledR}$, sisanya sebanyak 83,4 $\%$ responden tidak mengenal brand Root Beer - The Groovy Taste ${ }^{\circledR}$.

c. Promosi below the line yang sudah dijalankan saat ini dianggap kurang efektif dalam meningkatkan penjualan perusahaan bila tidak dibarengi dengan promosi above the line. Hal ini dapat dilihat dalam perbandingan cost ratio biaya promosi dibandingkan penjualan PT KMI pada tahun 2009 (Tabel 1.).

Tabel 1.

Perbandingan biaya promosi dengan penjualan PT KMI tahun 2009

\begin{tabular}{|c|c|c|r|r|r|}
\hline \multicolumn{2}{|c|}{ Anggaran Perusahaan } & \multicolumn{2}{|c|}{ Pencapaian Perusahaan } \\
\hline $\begin{array}{c}\text { Anggaran } \\
\text { Promosi (non } \\
\text { ATL) }\end{array}$ & $\begin{array}{c}\text { Target } \\
\text { Penjualan }\end{array}$ & $\%$ & $\begin{array}{c}\text { Biaya } \\
\text { Promosi (non } \\
\text { ATL) }\end{array}$ & Penjualan & $\%$ \\
\hline 1.725 & 11.336 & 15 & 1.264 & 4.079 & 31 \\
\hline \multicolumn{2}{|c|}{ Keterangan : angka promosi dan penjualan dalam jutaan rupiah } \\
\hline
\end{tabular}


d. Perusahaan belum melakukan promosi above the line yang mampu menarik perhatian massa dalam jumlah besar.

\subsection{Tujuan Penelitian}

Merumuskan strategi promosi above the line yang tepat untuk produk Root Beer The Groovy Taste ${ }^{\circledR}$ sehingga dapat meningkatkan brand awareness target pelanggan.

\section{$1.4 \quad$ Kerangka Berpikir}

Kerangka berpikir (Gambar 1.) merupakan rancangan efektivitas strategi promosi above the line, mulai dari analisa ekternal untuk mengetahui peluang dan ancaman yang akan mempengaruhi strategi promosi, analisis internal untuk mengukur kekuatan dan kelemahan, memformulasikan strategi promosi hingga ke jadwal implementasi strategi promosi.

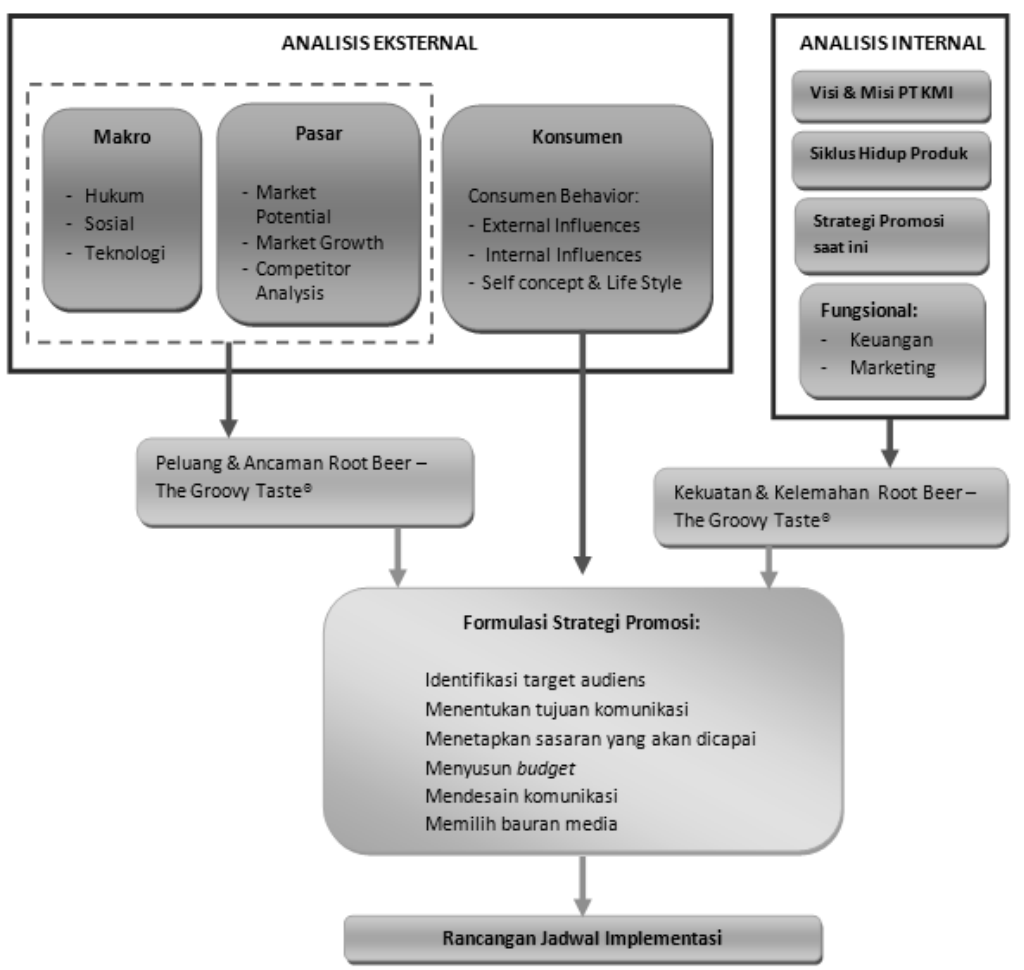

Gambar 1.

Kerangka Pemikiran Penulisan 


\section{TINJAUAN PUSTAKA}

\subsection{Definisi Promosi}

Belch and Belch (2007, hal. 15) mendefinisikan promosi sebagai usaha penjualan dengan membangun saluran komunikasi dan bujukan dalam menjual barang dan jasa. Dalam berpromosi perusahaan melakukan komunikasi dengan pelanggan untuk memberi informasi, membujuk dan mengingatkan pelanggan.

\subsection{Promotional Mix}

Alat bantu yang digunakan untuk mencapai tujuan komunikasi perusahaan adalah promotional mix yang terdiri atas:

- Advertising (iklan) didefinisikan dengan komunikasi nonpersonal yang dibayar untuk menampilkan produk dan jasa perusahaan atau ide-ide dari sponsor. Media periklanan terdiri dari: televisi, radio, koran, majalah, tabloid.

- Melalui internet marketing, Perusahaan mengiklankan produk dan jasanya pada website milik sendiri dan website milik perusahaan/organisasi lain, beriklan melalui sebuah link pada search engine.

- Direct marketing adalah salah satu cara perusahaan untuk berkomunikasi langsung dengan target pelanggan untuk menciptakan suatu transaksi. Direct marketing dapat berupa direct mail, direct order catalogs, direct sales, dan iklan-iklan yang direspon langsung melalui internet dan berbagai media siaran dan media cetak.

- Sales promotion didefinisikan sebagai suatu aktivitas marketing yang menyediakan nilai tambah atau insentif untuk para tenaga penjual, distribusi dan pelanggan agar penjualan dapat segera terjadi.

- Public relations didefinisikan sebagai suatu aktivitas untuk mempengaruhi tingkah laku publik, dan melaksanakan suatu program untuk mendapatkan pemahaman publik dan diterima oleh publik.

- Personal selling melibatkan kontak langsung antara penjual dan pembeli, dimana mereka dapat betatapan muka secara langsung atau melalui telepon.

\subsection{Brand Awareness}

Brand awareness adalah kemampuan seorang pembeli potensial untuk mengenali atau mengingat suatu merek dari kategori suatu produk tertentu. Menurut Aaker (1991, hal 62) tingkatan dalam brand awarenss dibagi menjadi empat tingkat yang disebut 'The Awareness Pyramid' yang ditunjukkan pada Gambar 2. 


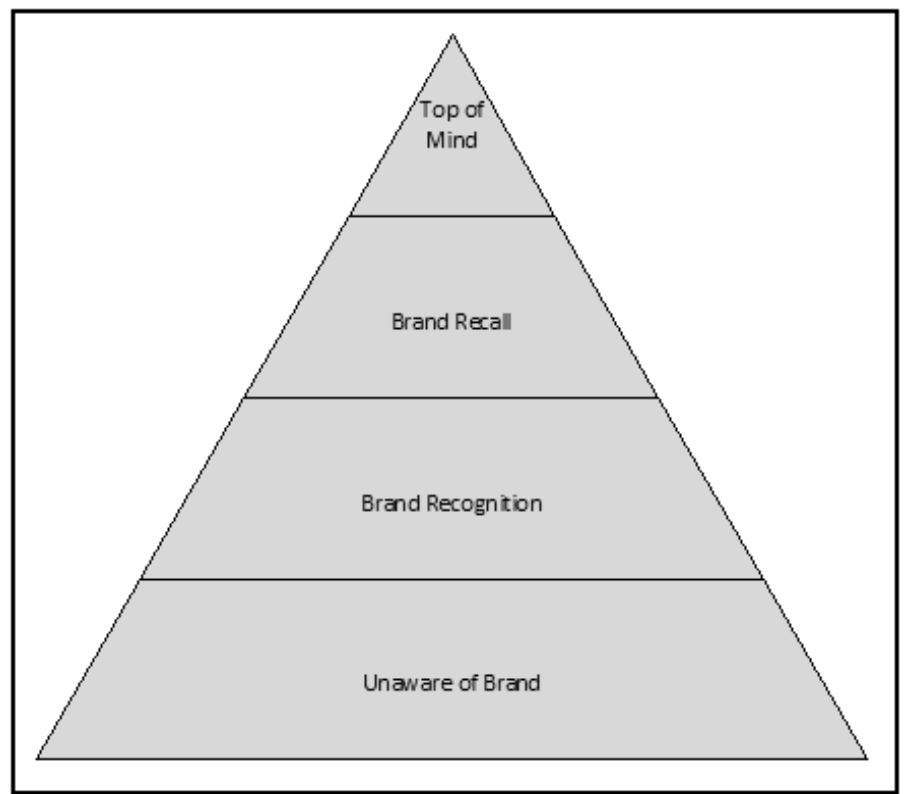

Gambar 2.

The Awareness Pyramid

\section{METODOLOGI}

\subsection{Jenis Penelitian}

Penelitian ini merupakan penelitian deskriptif dengan Single Cross-Sectional Design karena bersifat mejelaskan atau memberikan gambaran secara sistematik, faktual dan akurat, dilakukan dengan metode survei dan menggunakan kuesioner sebagai alat ukurnya.

\subsection{Pengelompokan Sampel Penelitian}

Responden dalam penelitian ini dibagi dalam dua kelompok usia (berdasarkan tahapan dalam Human Life Cycle), yaitu:

- Usia dewasa muda (young adulthood) berkisar antara 18 - 29 tahun.

- Usia dewasa (adulthood) berkisar antara 30 - 40 tahun.

\subsection{Jumlah Sampel Dalam Penelitian}

Jumlah penduduk Jakarta dan sekitarnya (Jabodetabek) pada tahun 2000 adalah sebesar 16.459.356 orang.

- Jumlah penduduk dengan usia 18-29 tahun: 3.863.340.

- Jumlah penduduk dengan usia 30-40 tahun: 2.561.076.

Sekalipun populasi penelitian sangat besar, namun mengingat keterbatasan waktu, tenaga dan biaya dari pihak peneliti, maka diputuskan bahwa jumlah sampel yang dipergunakan adalah sebesar 120 orang.

Sedangkan jumlah keseluruhan sampel yang dipergunakan dalam penelitian ini adalah berjumlah 210 orang dengan perincian sebagai berikut: 60 orang merupakan responden try out. 120 orang merupakan responden field research. 


\section{ANALISIS}

\subsection{Analisis Eksternal \\ 4.1.1 Analisis Makro}

Analisis makro didasarkan pada Key External Forces. Key External Forces yang berpengaruh terhadap promosi above the line adalah:

\section{Analisis Legal}

Faktor legal yang memberikan dampak kepada industri periklanan adalah hukum yang berhubungan dengan penggunaan bintang iklan.

a. Peraturan Menkominfo tahun 2007

Peraturan No.44/PER/M.KOMINFO/12/ 2007 menyebutkan bahwa agensi periklanan harus menggunakan aktor/aktris domestik, lokasi pembuatan dan segala sesuatu yang berhubungan dengan pembuatan iklan harus dilakukan di dalam negeri (Indonesia) dan oleh orang Indonesia.

Root Beer - The Groovy Taste ${ }^{\circledR}$ sendiri sebenarnya merupakan produk lokal. Karena mereknya dalam Bahasa Inggris orang menganggap Root Beer - The Groovy Taste ${ }^{\circledR}$ adalah minuman yang berasal dari luar negeri, sehingga peraturan Menkominfo ini akan menjadi ancaman bagi Root Beer - The Groovy Taste ${ }^{\circledR}$, karena sebagai produk lokal maka yang harus menjadi bintang iklan Root Beer - The Groovy Taste ${ }^{\circledR}$ haruslah aktor/aktris lokal/pribumi.

b. Peraturan Pemerintah Repubik Indonesia Nomor 69 Tahun 1999

Peraturan mengenai Label dan Iklan Pangan pada ayat (2) menyebutkan bahwa: penggunaan anak-anak berusia di bawah lima tahun secara tegas dilarang untuk mengiklankan pangan yang tidak secara khusus ditujukan untuk dikonsumsi oleh mereka.

Peraturan ini merupakan ancaman bagi Root Beer - The Groovy Taste ${ }^{\circledR}$ karena tidak dapat menggunakan bintang iklan anak-anak dibawah lima tahun.

1. Analisis Sosial

Saat ini orang-orang mulai sadar akan kesehatan dan mulai menerapkan gaya hidup sehat. Mereka mulai sadar bahwa terlalu banyak minum carbonated soft drink akan berdampak buruk pada kesehatan. Salah satu peyebab efek buruk carbonated soft drink terhadap kesehatan adalah penggunaan pemanis buatan (aspartame).

Hal ini menjadi peluang, dengan adanya promosi above the line, konsumen diharapkan mengetahui bahwa Root Beer - The Groovy Taste ${ }^{\circledR}$ menggunakan pemanis asli, sehingga konsumen tidak perlu merasa khawatir dan akan beralih untuk mengkonsumsi Root Beer - The Groovy Taste ${ }^{\circledR}$.

2. Analisis Teknologi

Salah satu perubahan teknologi yang revolusioner adalah internet. Internet mengubah setiap peluang dan ancaman dengan mengubah daur hidup produk, meningkatkan kecepatan distribusi, membuat produk dan pelayanan baru, menghapus batasan pasar geografis tradisional, dan mengubah trade-off antara standarisasi produk dengan fleksibilitas (David, 2009, hal.112).

Dengan semakin meningkatnya pengguna internet di Indonesia, maka internet merupakan media yang potensial dalam beriklan. Hal ini merupakan peluang bagi Root Beer - The Groovy Taste ${ }^{\circledR}$ untuk beriklan melalui media internet.

\subsubsection{Analisis Pasar}

Best (2005), menyatakan bahwa dalam menganalisis pasar, ada masukanmasukan penting seperti: 
a. Analisis Pasar Potensial

Pasar yang dimiliki oleh industri carbonated soft drink tidak lepas dari industri soft drink, hal ini juga menyebabkan carbonated soft drink memiliki pasar yang sama dengan soft drink, dimana pasar carbonated soft drink merupakan bagian dari pasar soft drink (Tabel 2.).

Tabel 2.

Jumlah peminum soft drink dan carbonated soft drink (CSD)

\begin{tabular}{|c|c|c|c|c|c|}
\hline \multirow{2}{*}{ Tahun } & \multicolumn{5}{|c|}{ Dalam Juta liter } \\
\cline { 2 - 6 } & 2007 & 2008 & 2009 & $\begin{array}{c}\text { Prediksi } \\
2010\end{array}$ & $\begin{array}{c}\text { Prediksi } \\
2011\end{array}$ \\
\hline $\begin{array}{c}\text { Konsumsi soft } \\
\text { drink (selain } \\
\text { CSD) }\end{array}$ & $2.059,64$ & $2.429,06$ & $2.561,53$ & $3.069,66$ & $3.612,69$ \\
\hline $\begin{array}{c}\text { Jumlah } \\
\text { konsumsi CSD }\end{array}$ & $1.025,75$ & 960,45 & 930,87 & 899,90 & 855,86 \\
\hline
\end{tabular}

Sumber : Departemen Perindustiran dan BPS (2010)

Dalam industri carbonated soft drink sendiri, jenis-jenis carbonated soft drink dibagi berdasarkan rasanya, yaitu Cola, limun, rasa buah (orange, strawberry, mango, dll) dan Sarsaparilla (atau lebih dikenal dengan istilah root beer). Dalam industri carbonated soft drink yang menduduki pasar paling besar adalah minuman dengan jenis Cola (61\%), rasa buah (28\%), limun (8\%) dan Sarsaparilla (3\%).

Walaupun pangsa pasar minuman jenis Sarsaparilla paling kecil diantara minuman carbonated soft drink yang lain, tetapi terjadi peningkatan jumlah konsumsi dari tahun ke tahun untuk jenis Sarsaparilla, serperti yang terlihat pada Tabel 3.

Tabel 3.

Jumlah konsumsi CSD jenis Sarsaparilla dan rasa lain (Cola, rasa buah dan limun)

\begin{tabular}{|c|c|c|c|c|c|}
\hline \multirow[t]{2}{*}{ Tahun } & \multicolumn{5}{|c|}{ Dalam Juta liter } \\
\hline & 2007 & 2008 & 2009 & $\begin{array}{c}\text { Prediksi } \\
2010\end{array}$ & $\begin{array}{c}\text { Prediksi } \\
2011\end{array}$ \\
\hline $\begin{array}{c}\text { Jumlah } \\
\text { konsumsi CSD } \\
\text { (selain } \\
\text { sarsaparilla) }\end{array}$ & 997,85 & 933,42 & 899,28 & 865,08 & 817,04 \\
\hline $\begin{array}{c}\text { Jumlah } \\
\text { konsumsi CSD } \\
\text { (sarsaparilla) }\end{array}$ & 27,90 & 27,02 & 31,59 & 34,82 & 38,83 \\
\hline $\begin{array}{c}\text { Total konsumsi } \\
\text { CSD }\end{array}$ & $1.025,75$ & 960,45 & 930,87 & 899,90 & 817,04 \\
\hline
\end{tabular}

Sumber : Departemen Perindustiran dan BPS (2010) 
Besarnya Current Market Demand dan Untapped Market Opportunity lebih lanjut ditunjukkan pada Gambar 3.

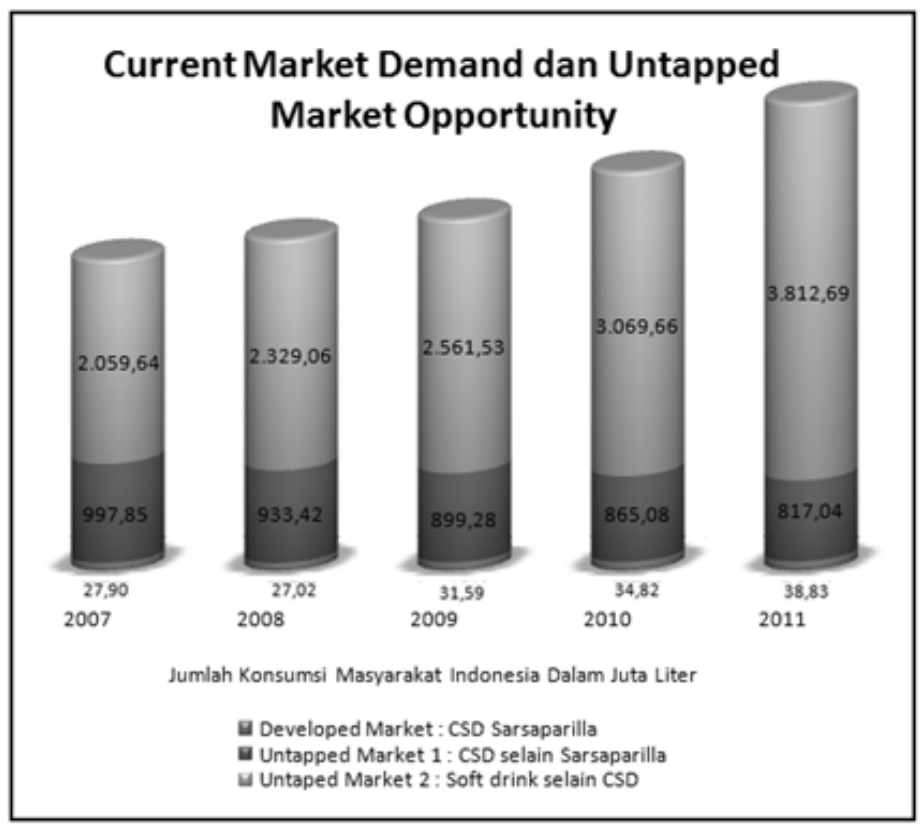

Gambar 3.

Current Market Demand dan Untapped Market Opportunity

Besarnya pasar potensial minuman diluar jenis Sarsaparilla pada tahun 2010, dan meningkatnya jumlah pasar potensial yang diprediksikan pada tahun 2010 hingga tahun 2011 menjadi peluang bagi minuman jenis Sarsaparilla, mengingat kemungkinan akan adanya peminum diluar Sarsaparilla untuk meminum jenis Sarsaparilla.

b. Analisis Pertumbuhan Pasar

Pertumbuhan pasar ketiga industri minuman pada Gambar 3. diatas ditunjukkan pada Tabel 4.

Tabel 4.

Pertumbuhan pasar soft drink Indonesia

\begin{tabular}{|c|c|c|c|c|c|c|}
\hline \multicolumn{1}{|c|}{ Tahun } & \multicolumn{5}{|c|}{ Dalam Juta liter } \\
\cline { 2 - 3 } & 2007 & 2008 & 2009 & $\begin{array}{c}\text { Prediksi } \\
2010\end{array}$ & $\begin{array}{c}\text { Prediksi } \\
2011\end{array}$ \\
\hline $\begin{array}{c}\text { Jumlah konsumsi soft } \\
\text { drink (selain CSD) }\end{array}$ & $2.059,64$ & $2.329,06$ & $2.561,53$ & $3.069,66$ & $3.812,69$ \\
\hline $\begin{array}{c}\text { Pertumbuhan konsumsi } \\
\text { soft drink (selain CSD) }\end{array}$ & - & $13,08 \%$ & $9,98 \%$ & $19,84 \%$ & $24,21 \%$ \\
\hline $\begin{array}{c}\text { Jumlah konsumsi CSD } \\
\text { (selain rasa Sarsaparilla) }\end{array}$ & 997,85 & 933,42 & 899,28 & 865,08 & 817,04 \\
\hline
\end{tabular}




\begin{tabular}{|c|c|c|c|c|c|}
\hline $\begin{array}{c}\text { Pertumbuhan pada CSD } \\
\text { (selain rasa Sarsaparilla) }\end{array}$ & - & $-6,46 \%$ & $-3,66 \%$ & $-3,80 \%$ & $-5,55 \%$ \\
\hline $\begin{array}{c}\text { Jumlah konsumsi CSD - } \\
\text { Sarsaparilla }\end{array}$ & 27,90 & 27,02 & 31,59 & 34,82 & 38,83 \\
\hline $\begin{array}{c}\text { Pertumbuhan pada CSD } \\
\text { - Sarsaparilla }\end{array}$ & - & $-3,15 \%$ & $16,91 \%$ & $10,22 \%$ & $11,52 \%$ \\
\hline
\end{tabular}

Sumber : Departemen Perindustiran dan BPS (2010)

\section{c. Analisis Persaingan}

Persaingan promosi above the line dari industri carbonated soft drink, datang dari pesaing Root Beer - The Groovy Taste ${ }^{\circledR}$ yaitu: Coca-cola, Fanta dan Sprite.

A\&W Root Beer belum beriklan baik di media cetak maupun di televisi atau radio. Selama ini promosi yang dilakukan oleh A\&W Root Beer hanya berfokus pada restoran $\mathrm{A} \& \mathrm{~W}$ saja.

Sedangkan dari industri soft drink (selain carbonated soft drink), Root Beer - The Groovy Taste ${ }^{\circledR}$ menghadapi persaingan promosi above the line yang sangat berat dengan minuman kesehatan, teh\&kopi, jus.

Jumlah biaya iklan yang dikeluarkan oleh para pesaing sangatlah besar, sebagai perusahaan yang baru berdiri tentulah budget iklan PT.KMI atas Root Beer - The Groovy Taste ${ }^{\circledR}$ tidak sebesar para pesaingnya. Hal ini menjadi ancaman bagi Root Beer - The Groovy Taste ${ }^{\circledR}$ dalam menghadapi persaingan iklan dengan para kompetitornya. Sedangkan bila dibandingkan dengan minuman carbonated soft drink jenis Sarsaparilla lainnya terbuka peluang bagi Root Beer - The Groovy Taste ${ }^{\circledR}$ karena untuk minuman jenis ini belum ada yang pernah membuat iklan untuk ditayangkan di media cetak, televisi maupun radio.

\subsubsection{Analisis Konsumen}

Dalam suatu pengambilan keputusan promosi, pemahaman yang jelas atas apa yang menjadi kebiasaan, fakor yang mempengaruhi keputusan pelanggan memutuskan apa yang akan dibelinya merupakan informasi penting yang dibutuhkan.

a. Faktor Eksternal

Terdapat perbedaan pada faktor-faktor eksternal antara kelompok usia young adulthood (18-29 tahun) dan adulthood (30-40 tahun) dalam hal kebiasaan minum dan yang mempengaruhi keputusan pembelian/minum minuman carbonated soft drink (CSD), seperti yang ditunjukkan pada Gambar 4. dan Gambar 5. Sedangkan pencarian informasi carbonated soft drink dapat dilihat pada Gambar 6. 


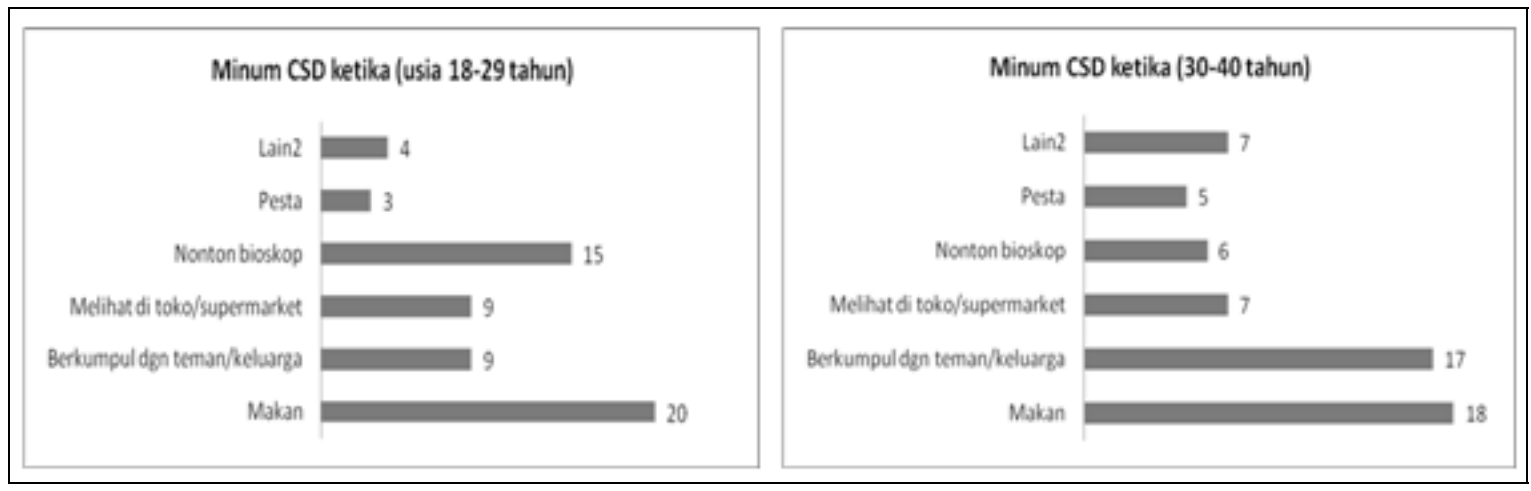

Gambar 4.

Perbedaan kebiasaan minum CSD pada usia 18-29 tahun dan 30-40 tahun.
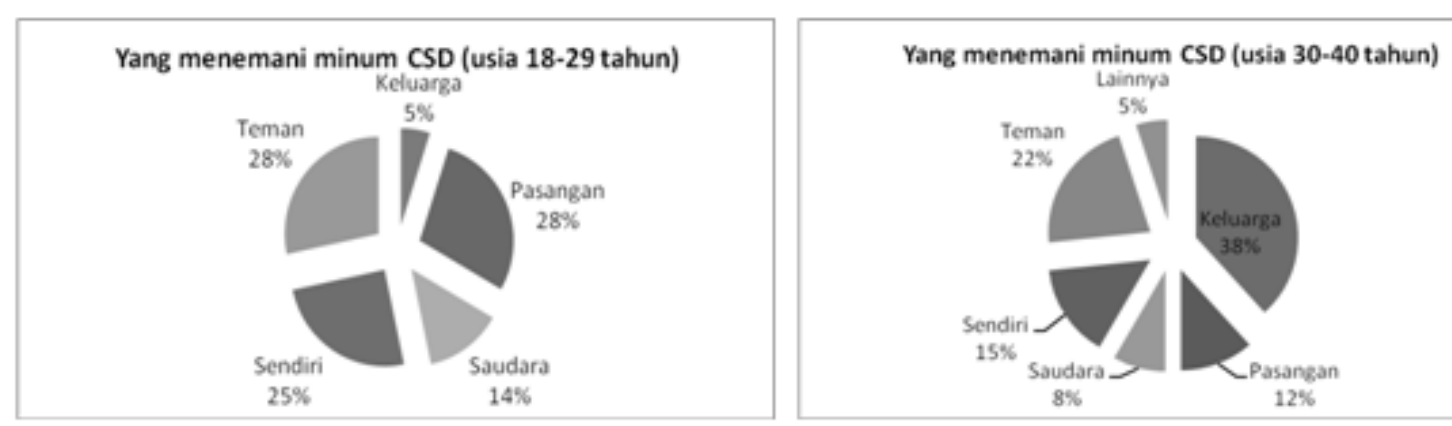

Gambar 5.

Perbedaan yang menemani responden dalam minum minuman CSD antara kelompok usia 18-29 tahun dan 30-40 tahun.

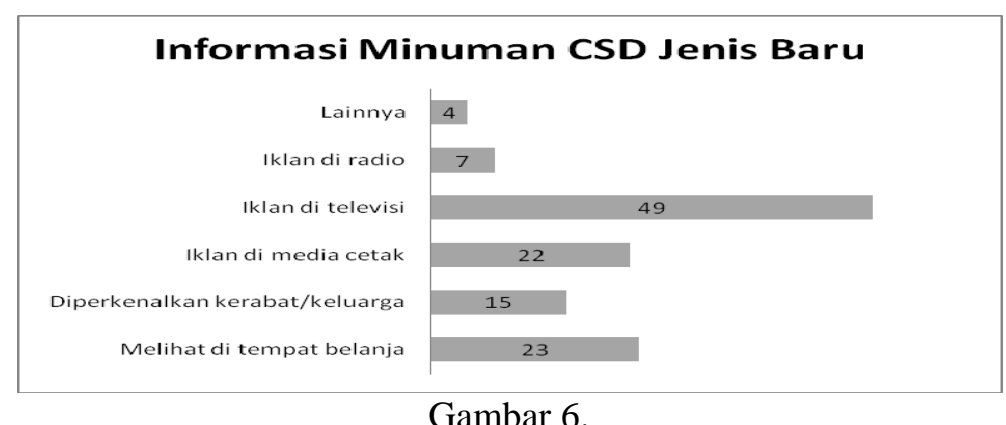

Pencarian informasi carbonated soft drink

Atas dasar inilah maka tepat bila Root Beer - The Groovy Taste ${ }^{\circledR}$ beriklan di televisi dan media cetak, dimana kedua media ini diharapkan mampu meningkatkan brand awareness Root Beer - The Groovy Taste ${ }^{\circledR}$. b. Faktor Internal

Faktor internal membahas mengenai halhal dari dalam diri individu yang mempengaruhi individu untuk menonton tayangan iklan. 
Kemudian agar iklan dapat terpapar dan mendapatkan perhatian oleh target audiens, maka menurut responden iklan tersebut perlu dibintangi oleh artis dan iklan tersebut diiringi oleh musik. Selain itu menurut responden, mereka lebih menyukai iklan yang mampu melibatkan emosional dan rasio/logis.

c. Self Concept dan Life Style
Self concept dan life style dari seseorang terbentuk dari pengaruh eksternal dan pengaruh internal dimana individu tersebut berada. Self concept dari responden ditunjukkan pada Tabel 5 . Sedangkan life style dari responden tercermin dalam pertanyaan mengenai hobi responden seperti yang ditunjukkan pada Gambar 7.

Tabel 5.

Self concept dari responden

\begin{tabular}{|c|c|c|c|c|c|c|c|}
\hline \multirow{3}{*}{ Sifat saya: } & A & B & c & D & E & \multirow{3}{*}{$\begin{array}{c}F= \\
A+B+C+D+E \\
\text { Jumlah } \\
\text { Responden }\end{array}$} & \multirow{3}{*}{$\begin{array}{c}\mathrm{G}=\text { tangga pan res ponden } \\
\mathrm{x} \text { bobot } \\
\text { Total bobot }\end{array}$} \\
\hline & \multicolumn{5}{|c|}{ Tanggapan Responden } & & \\
\hline & SS & 5 & BS & TS & STS & & \\
\hline coba hal baru & 13 & 73 & 23 & 8 & 3 & 120 & 445 \\
\hline praktis & 16 & 62 & 24 & 15 & 3 & 120 & 433 \\
\hline percaya diri & 13 & 54 & 42 & 9 & 2 & 120 & 427 \\
\hline mengikuti mode & 7 & 55 & 36 & 20 & 2 & 120 & 405 \\
\hline ceria & 4 & 52 & 48 & 11 & 5 & 120 & 399 \\
\hline rapi & 7 & 51 & 38 & 18 & 6 & 120 & 395 \\
\hline terja dwal & 9 & 49 & 27 & 26 & 9 & 120 & 383 \\
\hline
\end{tabular}

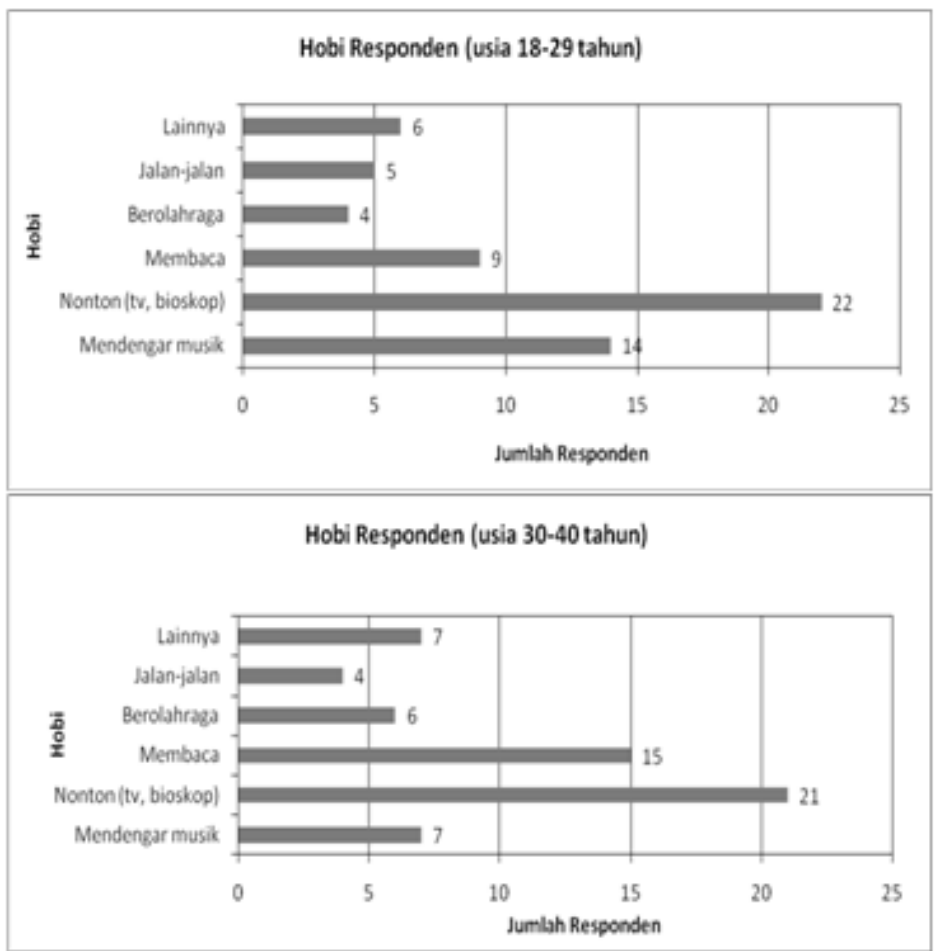

Gambar 7.

Perbedaan hobi kelompok usia 18-29 tahun dan 30-40 tahun 


\subsection{Analisis Internal}

Semua organisasi memiliki kekuatan dan kelemahan dalam area fungsional bisnisnya. Analisis internal merupakan salah satu kunci utama dalam merancang suatu strategi, dan apabila strategi yang dirancang merupakan strategi promosi, maka analisis internal dilakukan terhadap area-area fungsional yang berhubungan dengan fungsi promosi dari suatu perusahaan.

\subsubsection{Visi dan Misi PT KMI}

Visi dari PT KMI adalah: "Menjadi perusahaan beverage terkemuka di Indonesia”. Sedangkan misi dari PT KMI adalah: "Senantiasa menghasilkan minuman yang sehat tanpa menggunakan TigaP: pemanis buatan, pewarna buatan dan pengawet”.

PT KMI ingin menjadi perusahaan beverage tersebesar yang mengutamakan kesehatan peminumnya dengan tidak menggunakan pemanis buatan, pewarna buatan, perasa dan pengawet. Sehingga visi dan misi dari PT KMI ini lebih lanjut menjadi kekuatan bagi perusahaan karena tidak banyak perusahaan, terutama perusahaan minuman yang memegang prinsip peduli kesehatan seperti ini.

\subsubsection{Siklus Hidup Produk}

Bila dilihat dari stage characteristic, PT KMI masih berada pada tahap Introduction. Hal ini ditandai dengan penjualan yang masih rendah, profit yang masih negatif, dan berdasarkan periode yang sudah ditetapkan oleh perusahaan dimana perusahaan menginginkan berada pada tahap Introduction hanya dalam waktu 2 tahun sebelum pindah ke tahap berikutnya.

Posisi perusahaan yang masih berada pada tahap Introduction merupakan kelemahan bagi perusahaan, sebab minuman carbonated soft drink yang lain baik yang sejenis (rasa sarsaparilla) maupun yang tidak sejenis (rasa cola, lemon, jeruk, strawberry) sudah berada pada tahap Growth atau Mature, sehingga posisi perusahaan menjadi tertinggal baik dalam segi penjualan, laba dan market growth, maupun dari segi firm's normative response dimana strategi promosi yang masih terbatas pada meningkatkan brand awareness dan mengajak orang untuk mencoba Root Beer The Groovy Taste ${ }^{\circledR}$, lini produk yang masih terbatas dan saluran distribusi yang masih sempit. Posisi perusahaan saat ini masih lemah dalam hal tawar-menawar terhadap pemasok dan konsumen.

\subsubsection{Strategi Promosi Perusahaan Saat Ini}

Strategi promosi yang dilakukan oleh Root Beer - The Groovy Tatse ${ }^{\circledR}$ saat ini adalah Promosi $360^{\circ}$, yaitu menarget Root Beer - The Groovy Taste ${ }^{\circledR}$ sebagai pemimpin pasar minuman carbonated soft drink rasa Sarsaparilla. Promosi $360^{\circ}$ merupakan offensive strategy yang langsung menarget AW-Root Beer sebagai pesaing secara langsung ataupun carbonated soft drink lain seperti Coca-Cola, Fanta, Sprite, Pepsi, Mirinda, dll., dengan tujuan untuk meningkatkan pangsa pasar Root Beer - The Groovy Tatse ${ }^{\circledR}$.

Implementasi Promosi $360^{\circ}$ dari Root Beer - The Groovy Tatse ${ }^{\circledR}$ yang dilakukan oleh PT KMI dibagi menjadi 2 bagian, yaitu promosi above the line dan promosi below the line.

A. Promosi above the line

Sebenarnya PT KMI sudah memasukkan promosi above the line melalui televisi, media dan print dalam rencana Promosi $360^{\circ}$ dari Root Beer - The Groovy Tatse ${ }^{\circledR}$, tetapi hingga saat ini promosi above the line belum dilakukan karena masih berfokus pada produksi dan 
pendistribusian Root Beer - The Groovy Taste ${ }^{\circledR}$.

B. Promosi below the line

Berikut adalah promosi below the line yang sedang dijalankan oleh perusahaan:

1) Direct selling

Penjualan direct selling yang dilakukan PT KMI adalah dengan menggunakan SPG yang ditempakan di Key Account dan acara-acara untuk membagikan sampel produk, memberi informasi dan mengajak calon pelanggan untuk membeli Root Beer - The Groovy Taste ${ }^{\circledR}$.

2) Event

Event berupa pembukaan gerai pada acara-acara olah raga, pentas musik dan acara kesenian yang lain, penyusunan kaleng Root Beer - The Groovy Taste ${ }^{\circledR}$ raksasa di Ocean Park dalam rangka HUT Ocean Park, membuat mobil hias dari kaleng Root Beer - The Groovy Taste ${ }^{\circledR}$ dalam rangka memperingati HUT RI yang ke -64 .

3) Brand Activation

Kegiatan brand activation yang pernah dilakukan oleh perusahaan adalah: lomba kreasi membuat Root Beer float, membuat acara "bagi-bagi doorprize rejeki Root Beer - The Groovy Taste ${ }^{\circledR}$ " kepada pembeli Root Beer - The Groovy Taste ${ }^{\circledR}$ di beberapa Hypermarket, membagi-bagikan sampel Root Beer The Groovy Taste ${ }^{\circledR}$ dalam kemasan botol OWB di beberapa Key Account.

4) Trade Promo

Trade promo yang dijalankan oleh perusahaan adalah:

a. Space - perusahaan menyewa tempat4.3 khusus di Key Account untuk memajang produknya sehingga dapat menarik perhatian calon pembeli.

b. Katalog - perusahaan ikut serta dalam promo potongan harga murah yang diberikan oleh Key Account, dan Key
Account akan mencantumkan produk sponsor dalam katalog.

c. Free product - perusahaan memberikan promo kepada penjual berupa free product yaitu program 10 gratis 1 .

d. Price discount - yaitu berupa pemberian diskon kepada penjual agar penjual semakin tertarik untuk menjual/memasarkan produk Root Beer - The Groovy Taste®.

5) Consumer Promo

Biasanya consumer promo diberikan dalam bentuk gift atau merchandise.

6) Electric Cooler

Electric cooler, merupakan salah satu bentuk promosi yang berupa peminjaman lemari pendingin yang berbentuk kaleng Root Beer - The Groovy Taste ${ }^{\circledR}$ kepada Key Account.

Dapat disimpulkan, bahwa strategi Promosi $360^{\circ}$ yang saat ini dijalankan hanya promosi below the line dan belum berhasil meningkatkan jumlah peminum dan pendapatan Root Beer - The Groovy Taste ${ }^{\circledR}$. Bila promosi below the line yang saat ini sudah dijalankan oleh Root Beer terus ditingkatkan tanpa melakukan promosi above the line, akan membebani/merugikan bagi perusahaan karena cost to ratio biaya promosi akan meningkat dan peningkatannya tidak sebanding dengan jumlah peningkatan penjualan. Oleh karena itu, strategi pemasaran yang sudah dijalankan saat ini oleh Root Beer - The Groovy Taste ${ }^{\circledR}$ dianggap menjadi kelemahan dari Root Beer - The Groovy Taste ${ }^{\circledR}$ bila tidak dijalankan bersama dengan promosi above the line-nya.

\subsubsection{Analisis Fungsional}

Ada dua Departemen yang berhubungan atau berinteraksi langsung dengan promosi Root Beer - The Groovy Taste ${ }^{\circledR}$, yaitu Departemen Marketing dan Departemen Finance\&Accounting. 
a. Departemen Marketing

Sebagai perusahaan yang baru berdiri, PT KMI masih belum memiliki pengalaman dalam hal pembuatan promosi above the line. Hal ini menjadi kelemahan PT KMI, karena untuk jenis minuman carbonated soft drink jenis sarsaparilla di Indonesia belum pernah ada yang beriklan melalui media. PT KMI yang akan menjadi first mover bila beriklan melalui media. Sebagai first mover, PT KMI tidak memiliki data-data mengenai what (tema), how (cara penyampaian - creative strategy) dan who (siapa yang menyampaikan) yang dianggap tepat untuk menarik minat target audiens, selain itu manajemen PT KMI belum memiliki pengalaman dalam membuat iklan minuman carbonated soft drink.

b. Departemen Finance\&Accounting

Berdasarkan hasil perhitungan Divisi

Finance\&Accounting, budget yang dianggarkan untuk kebutuhan promosi above the line Root Beer - The Groovy Taste ${ }^{\circledR}$ adalah sebesar $30 \%$ dari penjualan Root Beer - The Groovy Taste ${ }^{\circledR}$.

Menurut hasil riset AC Nielsen tahun 2009 untuk new communication and product launching dibutuhkan 1500 2000 GRP (Gross Rating Point - jumlah rating televisi) dengan 1 rating poin bernilai antara Rp 1 juta - 1,5 juta. Bila mengacu pada hasil riset AC Nielsen, biaya iklan yang akan dikeluarkan oleh line Root Beer - The Groovy Taste ${ }^{\circledR}$ adalah sebesar $\mathrm{Rp} 1,5$ miliar -3 miliar/bulan.

Berdasarkan budget iklan yang dimiliki oleh PT KMI pada tahun 2010 dan 2011 banyaknya iklan yang mampu ditayangkan dapat dilihat pada Tabel 6.

Tabel 6.

Budget iklan dan banyaknya tayangan iklan PT KMI

\begin{tabular}{|c|c|c|c|c|}
\hline Tahun & \multicolumn{2}{|c|}{$\begin{array}{c}\text { Budget iklan (juta } \\
\text { rupiah) }\end{array}$} & $\begin{array}{r}\text { Banyaknya tayangan } \\
\text { iklan }\end{array}$ \\
\cline { 2 - 5 } & Minimum & Maksimum & Minimum & Maksimum \\
\hline 2010 & $2.555,7$ & $8.385,9$ & 1,7 bulan & 5,6 bulan \\
\hline 2011 & 2.903 & 11.613 & 1,9 bulan & 7,7 bulan \\
\hline
\end{tabular}

Bila dilihat dari sisi anggaran, hal ini kelemahan bagi Root Beer - The Groovy Taste ${ }^{\circledR}$ karena rendahnya budget iklan menyebabkan Root Beer - The Groovy Taste ${ }^{\circledR}$ belum mampu beriklan sebanyak standar yang ada. Sehingga ada resiko bahwa iklan yang ditampilkan Root Beer - The Groovy Taste ${ }^{\circledR}$ belum cukup untuk mengangkat brand awareness-nya karena kurangnya frekuensi iklan yang ditayangkan.

\subsection{Formulasi Strategi Promosi} 4.3.1 Identifikasi Target Audiens

Berdasarkan hasil survei yang dilakukan oleh penulis (Mei 2010), didapatkan hasil bahwa jumlah konsumsi carbonated soft drink responden berusia 1829 tahun lebih banyak daripada konsumsi 
responden yang berusia 30-40 tahun, maka ditetapkan primary target iklan Root Beer The Groovy Taste ${ }^{\circledR}$ adalah audiens yang berusia 18-29 tahun, dan secondary target iklan Root Beer - The Groovy Taste ${ }^{\circledR}$ adalah audiens yang berusia 30-40 tahun.

\subsubsection{Tujuan Komunikasi}

Tujuan dari iklan Root Beer - The Groovy Taste ${ }^{\circledR}$ adalah:

a. menginformasikan adanya produk minuman Root Beer - The Groovy Taste ${ }^{\circledR}$ yang mampu memberikan rasa segar pada peminumnya, minuman dengan rasa yang ringan dan mampu memberi kesan ceria pada peminumnya, serta tidak berdampak buruk pada kesehatan (dengan menggunakan pemanis asli) agar dapat meningkatkan awareness dari target pelanggan.

b. membuat target edukasi tertarik untuk mencoba merasakan Root Beer - The Groovy Taste ${ }^{\circledR}$.

Pesan yang akan disampaikan oleh iklan Root Beer - The Groovy Taste ${ }^{\circledR}$ akan digunakan perpaduan antara rational appeals (digunakan untuk menekankan unsur kesehatan, tanpa pemanis buatan) dan unsur emotional appeals (digunakan untuk menggambarkan kesan segar, ceria yang didapat bila mengkonsumsi Root Beer - The Groovy Taste $\left.{ }^{\circledR}\right)$.

\subsubsection{Sasaran Yang Akan Dicapai}

Berdasarkan penelitian McDonald \& Sharp, batasan brand awaress produk beverage adalah sebesar $44 \%$ dari target market-nya mengenal merek produk tersebut. Batasan brand awareness yang ingin dicapai oleh PT KMI dengan adanya iklan Root Beer - The Groovy Taste ${ }^{\circledR}$ adalah sebesar 50\%.

\subsubsection{Budget}

Budget promosi yang dianggarkan oleh PT KMI untuk beriklan adalah sebesar
30\% dari penjualan Root Beer - The Groovy Taste ${ }^{\circledR}$, dimana budget yang dianggarkan tidak termasuk dalam biaya produksi iklan dan penggunaan artis talent. Untuk pembuatan iklan televisi membutuhkan biaya sekitar Rp 250 juta, sedangkan biaya produksi untuk media cetak adalah sekitar Rp 25 juta. Selain itu, bila iklan yang akan ditayangkan menggunakan aktor/artis sebagai simbol untuk mewakili Root Beer The Groovy Taste ${ }^{\circledR}$, maka akan ada biaya artis talent - dimana aktor/artis akan dikontrak selama periode tertentu untuk menjadi simbol dan mewakili produk Root Beer - The Groovy Taste ${ }^{\circledR}$, dan tidak diperbolehkan untuk membintangi iklan produk sejenis. Berdasarkan pengalaman Sales \& Marketing Dept. Head PT KMI kisaran biaya yang akan dikeluarkan untuk 1 orang artist talent mencapai Rp 75 juta - Rp 300 juta.

Berdasarkan keputusan manajemen PT KMI, budget iklan Root Beer - The Groovy Taste ${ }^{\circledR}$ yang dianggarkan untuk tahun 2010 adalah Rp 10 Miliar.

\subsubsection{Desain Komunikasi}

Bila berbicara mengenai desain komunikasi, maka ada 3 hal yang perlu dibahas yaitu:

a. Message Strategy

Yang akan menjadi tagline dari iklan Root Beer - The Groovy Taste ${ }^{\circledR}$ ini adalah: The Groovy Taste. Berdasarkan keterangan dari Manajemen PT KMI, kata Groovy identik dengan adalah menyenangkan, modis, bergairah, informal, manis dan menuntut ide baru.

b. Creative Strategy

Efektivitas dari komunikasi bergantung pada bagaimana pesan disampaikan. Creative strategy merupakan cara marketer untuk menterjemahkan pesan mereka menjadi suatu bentuk komunikasi dengan target audiens. 
Berdasarkan hasil survei, didapatkan bahwa istilah Groovy menurut responden adalah: musik, tari dan gembira, sehingga pesan yang akan disampaikan dalam iklan ini adalah: The Groovy Taste, yang digambarkan dengan musik, tarian dan kegembira.

Target audiens iklan Root Beer - The Groovy Taste ${ }^{\circledR}$ dibagi menjadi dua, yaitu:

\section{- Primary Target Audiens}

Dari hasil survei yang dilakukan didapatkan bahwa self concept dari primary target audiens adalah: mencoba hal-hal baru, praktis dan mengikuti trend/mode saat ini. Hobi dari primary target audiens adalah: nonton (televisi atau bioskop), mendengarkan musik dan membaca. Responden berpendapat bahwa suasana yang tepat untuk sebuah iklan carbonated soft drink adalah dengan menampilkan kesegaran orang yang sedang minum carbonated soft drink dan sedang berkumpul bersama dengan teman-teman.

Berdasarkan self concept, hobi dan pendapat responden mengenai suasana iklan carbonated soft drink, maka creative strategy-nya adalah dengan tema musik dan atau tarian yang gaul, dalam suasana yang gembira, dimana musik dan tarian ini dilakukan bersama teman-teman dan juga menampilan kesegaran minuman Root Beer - The Groovy Taste ${ }^{\circledR}$. Creative strategy ini akan didiskusikan dengan pihak agensi yang akan mewakili PT KMI, untuk kemudian dikembangkan menjadi suatu konsep iklan.

- Secondary Target Audiens

Dari hasil survei yang dilakukan didapatkan bahwa self concept dari secondary target audiens adalah: percaya diri, menyukai hal-hal baru, dan rapi. Responden berpendapat bahwa suasanya yang tepat untuk sebuah iklan carbonated soft drink adalah dengan menampilkan kesegaran minuman carbonated soft drink dan ketika sedang berkumpul bersama dengan keluarga

Berdasarkan self concept, hobi dan pendapat responden mengenai suasana iklan carbonated soft drink, maka creative stategy iklan The Groovy Taste untuk secondary target audiens adalah dengan tema berkumpul bersama keluarga, dalam suasana yang gembira dan juga menampilan kesegaran minuman Root Beer - The Groovy Taste ${ }^{\circledR}$. Selain itu iklan untuk secondary target audiens akan menekankan unsur "tanpa pemanis buatan".

c. Message Source

Dari hasil survei terhadap primary target audiens, didapatkan bahwa yang menjadi artis favorit mereka adalah: Agnes Monica. Agnes Monica dianggap mampu mewakili citra dari generasi muda saat ini.

\subsubsection{Memilih Bauran Media}

Dengan budget iklan yang terbatas, PT KMI perlu menentukan bauran media iklan yang tepat, agar iklan menjadi tepat sasaran sehingga tujuan komunikasi dapat dicapai.

Berikut adalah pilihan media untuk beriklan Root Beer - The Groovy Taste $\AA$ :

a. Televisi

Televisi merupakan media beriklan yang tepat untuk memperkenalkan suatu produk baru atau untuk meningkatkan brand awareness. Televisi memberikan dampak yang kuat terhadap konsumen, karena memberikan tekanan pada dua indra sekaligus yaitu: penglihatan dan pendengaran.

Menurut tanggapan manajemen PT KMI televisi merupakan media iklan yang biaya/orangnya paling rendah. 
b. Radio

Menurut tanggapan manajemen, untuk produk baru terutama produk-produk beverage tidaklah tepat menggunakan radio untuk meningkatkan awareness, sebab salah satu kelemahan dari radio adalah tidak ada visualisasi, konsumen dituntut untuk menggunakan imajinasinya untuk membayangkan gambaran produk ketika mendengar iklan radio. Bila konsumen belum pernah melihat iklan dan tidak memiliki pengetahuan atas produk Root Beer The Groovy Taste ${ }^{\circledR}$, maka akan terjadi kesalahan penafsiran. Iklan melalui radio dianggap kurang tepat untuk Root Beer The Groovy Taste ${ }^{\circledR}$ dalam rangka meningkatkan awareness

c. Koran

Koran bukanlah tempat favorit untuk mengiklankan minuman soft drink. Seluruh jenis minuman soft drink (health drink, fruit \& vegetabe juice, syrup, coffee \& tea, carbonated soft drink, non carbonated soft drink) belum pernah menduduki posisi 45 besar Newspaper Advertising Expenditure By Product Category.

Kertas koran yang kurang baik dimana mudah robek dan warna yang kurang jelas, membuat minuman soft drink jarang beriklan di koran karena soft drink membutuhkan warna dan gambar yang menarik untuk mempengaruhi pembacanya sehingga tertarik untuk mencoba/membeli minuman tersebut.

d. Majalah dan Tabloid

Majalah dan Tabloid mampu mengatasi permasalahan yang dihadapi bila beriklan melalui koran, yaitu kualitas kertas majalah dan tabloid yang jauh lebih baik dibandingkan koran sehingga kertas tidak mudah robek dan warna terlihat lebih jelas, selain itu target pembaca dari majalah dan tabloid lebih fokus bila dibandingkan dengan koran.

e. Internet Marketing

Sampai saat ini internet marketing belum menjadi alternatif bagi PT KMI untuk beriklan, hal ini disebabkan PT KMI belum memiliki divisi IT sendiri. Manajemen beranggapan bahwa internet belum efektif bila brand awareness masih rendah, sebab kemungkinan orang malas untuk melakukan pencarian informasi melalui search engine atau website perusahaan bila konsumen sendiri masih belum merasa familiar dengan produk ini.

Berdasarkan penjabaran di atas, maka media yang tepat bagi Root Beer - The Groovy Taste ${ }^{\circledR}$ untuk beriklan adalah televisi dan media cetak (majalah dan tabloid). Pada media cetak, penampilan iklan Root Beer - The Groovy Taste ${ }^{\circledR}$ dapat dilakukan dalam 3 jenis, yaitu:

- Display advertising, menampilkan iklan utama pada majalah dengan ukuran $1 / 2$ - 1 halaman dengan tampilan berwarna.

- Info produk, menampilkan ulasan singkat mengenai produk Root Beer The Groovy Taste ${ }^{\circledR}$.

- Banner advertising, iklan kecil berukuran 1/8 - 1/4 halaman yang berfungsi sebagai penarik perhatian dan mengingatkan target audiens pada produk Root Beer - The Groovy Taste ${ }^{\circledR}$. Setelah menentukan bauran media yang akan dipilih yaitu: televisi, majalah dan tabloid, maka langkah selanjutnya adalah menentukan besarnya budget yang akan dikeluarkan untuk beriklan di televisi, majalah dan tabloid.

Berdasarkan hasil survei Nielsen Media Research tahun 2009 mengenai Advertising Expenditure, didapatkan bahwa total Advertising Expenditure selama tahun 2009 adalah sebesar Rp 53.058 miliar, 
dimana budget untuk televisi adalah sebesar Rp 29.182 (55\%), majalah sebesar Rp 3.138 miliar (6\%), tabloid Rp 1.592 miliar (3\%) dan gabungan antara koran, outdor dan radio sebesar Rp 19.101 miliar (36\%).

Budget yang dimiliki PT KMI untuk iklan Root Beer - The Groovy Taste ${ }^{\circledR}$ adalah sebesar Rp 10 miliar. Berdasarkan hasil survei yang dilakukan oleh Nielsen Media Reserach, maka budget yang akan dialokasikan untuk iklan di televisi adalah sebesar Rp 8,5 miliar (55/64 x Rp 10 miliar), iklan di majalah sebesar Rp 1 miliar (6/64 x Rp 10 miliar) dan iklan di tabloid adalah sebesar Rp 500 juta (3/64 x Rp 10 miliar).

\subsection{RANCANGAN IMPLEMENTASI}

\subsubsection{Pemilihan Pola Waktu Beriklan di Media}

Dalam peluncuran produk baru, pengiklan harus memilih antara continuous, concentrated dan intermittent.

a. Continuous - iklan akan ditayangkan secara terus-menerus sepanjang periode iklan. b. Concentrated - iklan difokuskan pada suatu periode tertentu.

c. Intermittent - iklan ditayangkan pada suatu periode waktu tertenu, kemudian ada jeda dimana iklan tidak ditayangkan, kemudian iklan muncul lagi, dst.

Menurut pendapat manajemen PT

KMI. Continuos-alternating merupakan pilihan waktu beriklan yang tepat bagi Root Beer - The Groovy Taste ${ }^{\circledR}$ dalam beriklan, dengan mempertimbangkan budget iklan PT KMI yang terbatas dan iklan perlu ditayangkan secara terus-menerus untuk mendapatkan awareness dari audiens tetapi dengan frekuensi yang naik-turun untuk mengantisipasi kebosanan yang mungkin timbul akibat beriklan terus-menerus. Bila konsumen sudah bosan terhadap iklan maka akan berdampak buruk pada iklan tersebut.

\subsubsection{Pilihan Iklan di Televisi}

Berikut adalah jawaban responden kelompok usia 18-29 tahun mengenai judul acara televisi, jam tayang stasiun televisi yang paling sering ditonton serta rating acara tersebut (Tabel 7.).

Tabel 7.

Acara televisi, Jam tayang, Stasiun Televisi dan Rating televisi pilihan Responden Usia 18-29 Tahun

\begin{tabular}{|c|c|c|c|c|c|c|c|c|c|c|c|}
\hline \multicolumn{4}{|c|}{ Pilihan 1} & \multicolumn{4}{|c|}{ Pilihan 2} & \multicolumn{4}{|c|}{ Pilihan 3} \\
\hline $\begin{array}{l}\text { Judul } \\
\text { Aca ra }\end{array}$ & $\begin{array}{c}\text { Jam } \\
\text { tonton }\end{array}$ & $\begin{array}{c}\text { Stasiun } \\
\text { TV }\end{array}$ & $\begin{array}{c}\text { Respon- } \\
\text { den }\end{array}$ & $\begin{array}{l}\text { Judul } \\
\text { Aca ra }\end{array}$ & $\begin{array}{c}\text { Jam } \\
\text { tonton }\end{array}$ & $\begin{array}{c}\text { Stasiun } \\
\text { TV }\end{array}$ & $\begin{array}{c}\text { Respon- } \\
\text { den }\end{array}$ & $\begin{array}{l}\text { Judul } \\
\text { Aca ra }\end{array}$ & $\mid \begin{array}{c}\text { Jam } \\
\text { tonton }\end{array}$ & $\begin{array}{c}\text { Stasiun } \\
\text { TV }\end{array}$ & $\begin{array}{c}\text { Respon- } \\
\text { den }\end{array}$ \\
\hline $\begin{array}{l}\text { Opera } \\
\text { Van Java }\end{array}$ & $19-21$ & Trans 7 & 19 & \begin{tabular}{|l|} 
Take \\
Celebrity \\
Out 2010 \\
\end{tabular} & $19-21$ & Indosiar & 15 & $\begin{array}{l}\text { Cinta } \\
\text { Fitri }\end{array}$ & $19-21$ & SCTV & 10 \\
\hline $\begin{array}{l}\text { Top } 9 \\
\text { News }\end{array}$ & $21-23$ & $\begin{array}{l}\text { Metro } \\
\text { TV }\end{array}$ & 10 & Silet & $09-12$ & $\mathrm{RCTI}$ & 10 & $\begin{array}{l}\text { Liputa n } 6 \\
\text { Pagi }\end{array}$ & $05-09$ & SCTV & 11 \\
\hline \begin{tabular}{|l} 
Buka n 4 \\
Mata \\
\end{tabular} & $21-23$ & Trans 7 & 8 & $\begin{array}{l}\text { Sport } 7 \\
\text { Malam }\end{array}$ & $23-01$ & Trans 7 & 7 & Sergap & $12-15$ & $\mathrm{RCTI}$ & 9 \\
\hline $\begin{array}{l}\text { Bioskop } \\
\text { Trans TV } \\
\end{array}$ & $21-23$ & Trans TV & 8 & $\begin{array}{l}\text { Terme hek- } \\
\text { mehek }\end{array}$ & $17-19$ & Trans 7 & 5 & $\begin{array}{l}\text { Highli ght } \\
\text { Otomotif }\end{array}$ & $12-15$ & Trans 7 & 6 \\
\hline \multicolumn{3}{|c|}{ Lain-lain } & 15 & \multicolumn{3}{|c|}{ Lain-lain } & 23 & \multicolumn{3}{|c|}{ Lain-lain } & 24 \\
\hline \multicolumn{3}{|c|}{ TOTAL RESPONDEN } & 60 & \multicolumn{3}{|c|}{ TOTAL RESPONDEN } & 60 & \multicolumn{3}{|c|}{ TOTAL RESPONDEN } & 60 \\
\hline
\end{tabular}

Berdasarkan tabel di atas, didapatkan total rating acara televisi pilihan responden adalah sebesar 129, hal ini diasumsikan bila iklan Root Beer - The Groovy Taste ${ }^{\circledR}$ 
disiarkan di seluruh acara televisi di atas, maka iklan Root Beer - The Groovy Taste ${ }^{\circledR}$ mampu menjangkau $129 \%$ penonton televisi di Indonesia.

Setelah mendapatkan total rating televisi, kemudian perusahaan juga perlu menentukan berapa besar tingkat awareness yang mampu didapatkan bila memasang iklan pada acaraacara televisi yang sudah dipilih pada Tabel 12. Ilustrasi tingkat awareness yang akan didapat oleh Root Beer - The Groovy Taste ${ }^{\circledR}$ ditunjukkan pada Gambar 8.

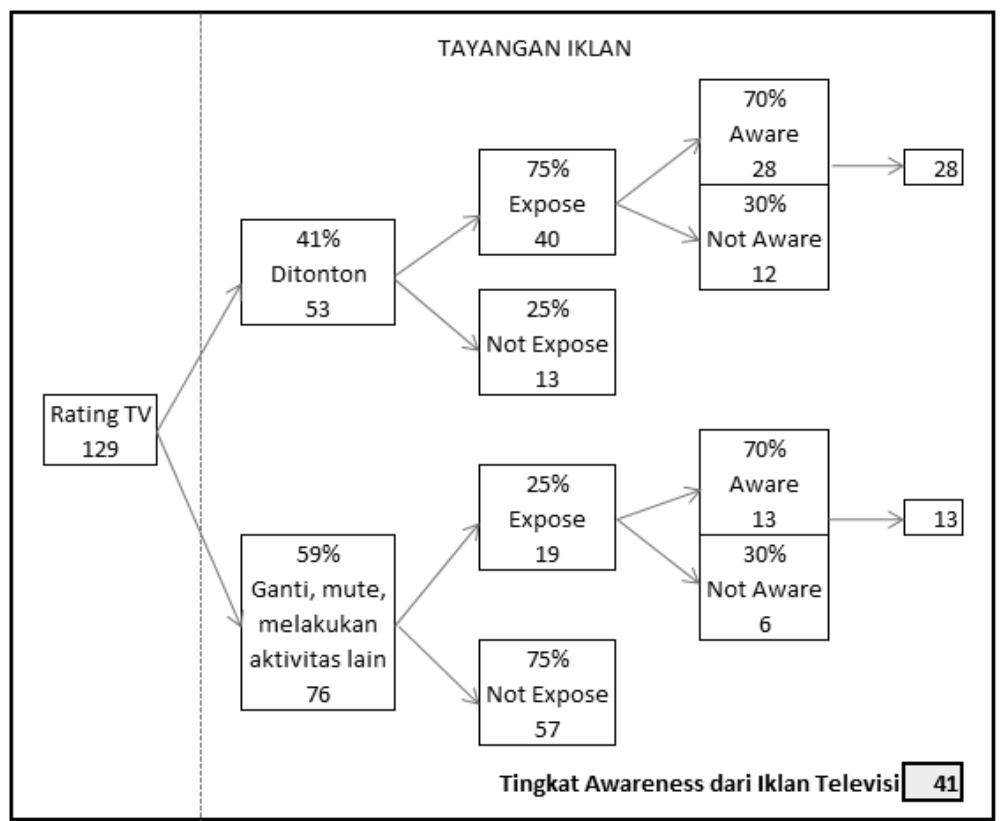

Gambar 8.

Tingkat awareness yang didapatkan Root Beer - The Groovy Taste ${ }^{\circledR}$ bila beriklan di televisi

\subsubsection{Pilihan Iklan di Majalah dan Tabloid}

Berikut adalah jawaban responden kelompok usia 30-40 tahun yang merupakan secondary target iklan Root Beer - The
Groovy Taste ${ }^{\circledR}$ mengenai judul majalah dan/atau tabloid yang dibaca, serta rating dari majalah/tabloid tersebut yang ditunjukkan pada Tabel 8.

Tabel 8.

Judul dan rating dari majalah/tabloid yang dibaca responden kelompok usia 30-40 tahun

\begin{tabular}{|c|c|c|c|c|c|c|c|c|c|c|c|}
\hline \multicolumn{4}{|c|}{ Plllhan 1} & \multicolumn{4}{|c|}{ Plllhan 2} & \multicolumn{4}{|c|}{ Plllhan 3} \\
\hline Judul & $\mathrm{M} / \mathrm{T}$ & Terblt & Rating & Judul & $\mathrm{M} / \mathrm{T}$ & Terblt & Rating & Judul & $\mathrm{M} / \mathrm{T}$ & Terblt & Rating \\
\hline HI dayah & $M$ & Minggua n & 3 & Otomotif & $\mathrm{T}$ & MInggua n & 1 & Femına & $\mathrm{M}$ & MInggua n & 0,7 \\
\hline Bola & $T$ & $\begin{array}{l}2 \times 1 \\
\text { minggu }\end{array}$ & 3 & Kartınl & $M$ & $\begin{array}{l}\text { Dua } \\
\text { mingguan }\end{array}$ & 1 & Tempo & $M$ & MIngguan & 1 \\
\hline Nova & $T$ & MIngguan & 1 & $\begin{array}{l}\text { Motor } \\
\text { Plus }\end{array}$ & T & $\begin{array}{l}\text { Dua } \\
\text { mIngguan }\end{array}$ & 2 & Senlor & $T$ & $\begin{array}{l}\text { Dua } \\
\text { mIngguan }\end{array}$ & 1 \\
\hline $\begin{array}{l}\text { Cosmo- } \\
\text { politan }\end{array}$ & $\mathrm{M}$ & Bulanan & 0,4 & soccer & $T$ & $\begin{array}{l}\text { Dua } \\
\text { mingguan }\end{array}$ & 1 & $\begin{array}{l}\text { Bintang } \\
\text { Indonesla }\end{array}$ & $\mathrm{T}$ & MIngguan & 0,8 \\
\hline
\end{tabular}

Keterangan: $\mathrm{M}=$ Majalah; $\mathrm{T}=$ Tabloid

Sumber: Media Scene (Volume 20, 2009) 
Total rating majalah dan tabloid pilihan responden kelompok usia 30-40 tahun adalah sebesar 16 , hal ini berarti bahwa Bila iklan Root Beer - The Groovy Taste ${ }^{\circledR}$ ditampilkan pada majalah dan tabloid pilihan responden, maka iklan Root Beer - The Groovy Taste ${ }^{\circledR}$ mampu menjangkau $16 \%$ pembaca media cetak di seluruh Indonesia.

Jumlah awareness yang didapatkan dari iklan Root Beer - The Groovy Taste ${ }^{\circledR}$ yang ditayangkan di televisi, majalah dan tabloid adalah sebesar 50\% (41\% didapat dari iklan di televisi dan 9\% didapat dari iklan di majalah/tabloid). Target awareness Root Beer - The Groovy Taste ${ }^{\circledR}$ yang ingin dicapai oleh PT KMI adalah sebesar melalui promosi above the line adalah 50\%. Bila perusahaan beriklan pada acara televisi, majalah dan tabloid pilihan responden, maka tingkat awareness yang didapatkan adalah sebesar 50\% yang berarti 50\% target audiens peminum carbonated soft drink mampu mengenali Root Beer - The Groovy Taste ${ }^{\circledR}$. Hal ini berarti bahwa target awareness yang ditetapkan perusahaan tercapai.

\subsubsection{Efisiensi Biaya}

Sebelum menentukan saluran televisi ataupun majalah dan tabloid yang akan dipilih untuk menampilkan iklan Root Beer The Groovy Taste ${ }^{\circledR}$, maka perlu dipertimbangkan efisiensi biayanya. Efisiensi biaya ini bertujuan untuk mengetahui seberapa besar biaya iklan per orang target audiens. Efisiensi biaya iklan televisi menjadi bahan pertimbangan yang penting bagi PT KMI dalam menentukan alokasi iklan Root Beer - The Groovy Taste ${ }^{\circledR}$, sebab porsi budget iklan terbesar akan dihabiskan untuk beriklan di televisi. Begitu pula dengan biaya iklan media cetak. Besar/kecilnya biaya iklan per individu ditentukan oleh besar/kecilnya total biaya iklan yang harus dikeluarkan dan jumlah orang yang melihat televisi dan pembaca media cetak tersebut. Idealnya semakin kecil biaya iklan per individu akan semakin baik.

\section{KESIMPULAN DAN SARAN}

Rendahnya tingkat awareness produk Root Beer - The Groovy Taste ${ }^{\circledR}$ menyebabkan target penjualan dan target laba PT Kreasi Mas Indah (PT KMI) yang sudah diproyeksikan tidak tercapai.

Ancaman yang dihadapi oleh Root Beer - The Groovy Taste ${ }^{\circledR}$ adalah, produkproduk pesaing baik carbonated soft drink maupun soft drink yang sudah memiliki brand yang cukup dikenal dan beriklan dengan cukup gencar di berbagai media. Selain itu ancaman lain adalah penurunan jumlah peminum carbonated soft drink pada umumnya yang disebabkan oleh munculnya berbagai variasi minuman ringan seperti: minuman isotonik, minuman kesehatan, jus, kopi, teh, dll.

Peluang yang dihadapi oleh Root Beer - The Groovy Taste ${ }^{\circledR}$ adalah walaupun terjadi penurunan jumlah peminum carbonated soft drink pada umumnya, tetapi carbonated soft drink jenis Sarsaparilla atau lebih dikenal dengan sebutan Root Beer mengalami peningkatan jumlah peminum.

Analisa konsumen menunjukkan terdapat perbedaan faktor eksternal, self concept dan hobi yang mempengaruhi keputusan minum carbonated soft drink antara kelompok usia 18-29 tahun dan 30-40 tahun. Perbedaan ini akan menyebabkan perbedaan dalam message strategy dan creative strategy dalam perumusan formulasi strategi promosi.

Kekuatan yang dimiliki oleh Root Beer - The Groovy Taste ${ }^{\circledR}$ adalah: produk minuman carbonated soft drink yang peduli 
pada kesehatan peminumnya, yaitu tidak mengandung pemanis buatan (aspartame).

Kelemahan yang dimiliki oleh Root Beer - The Groovy Taste ${ }^{\circledR}$ adalah: Siklus hidup produk berada pada tahap introduction - penjualan masih rendah dan laba masih negatif, promosi below the line yang saat ini dijalankan masih belum efektif, departmen marketing yang belum berpengalaman dalam membuat iklan serta budget iklan yang minim.

Pada formulasi strategi promosi, target audiens yang akan disasar oleh Root Beer - The Groovy Taste ${ }^{\circledR}$ dibagi menjadi dua kelompok, yaitu primary target merupakan target audiens yang berusia 18-29 tahun, dimana untuk menyasar target ini media iklan yang dipilih adalah televisi dan secondary target merupakan target audiens yang berusia 30-40 tahun, dimana untuk menyasar target ini media iklan yang dipilih adalah media cetak (majalah dan tabloid). Message strategy untuk kedua kelompok ini juga berbeda, bila primary target lebih mengutamakan suasana berkumpul dengan teman-teman tetapi untuk secondary target lebih mengutamakan suasana berkumpul dengan keluarga.

Keputusan pemilihan stasiun televisi, majalah dan tabloid sangatlah bergantung pada rating biaya yang akan dikeluarkan. Semakin tinggi efisiensi biaya per orang, maka semakin besar penghematan biaya iklan yang dikeluarkan oleh perusahaan.

Dalam penentuan strategi promosi iklan, perusahaan perlu melakukan analisa konsumen, sehingga dapat dibuat iklan yang tepat bagi target konsumen yang mampu meningkatkan awareness target

Dalam pemilihan saluran televisi, majalah dan tabloid yang akan menayangkan iklan Root Beer - The Groovy Taste ${ }^{\circledR}$, perusahaan perlu memperhatikan rating acara tevisi, majalah dan tabloid tersebut.

Mengingat budget iklan yang terbatas, maka PT KMI perlu mengkombinasikan durasi lama iklan di televisi dan besar iklan yang akan tayang pada majalah/tabloid. Pada awal penayangan iklan Root Beer - The Groovy Taste ${ }^{\circledR}$ sebaiknya menampikan tayangan iklan secara lengkap, setelah beberapa saat durasi lama tayang dapat dikurangi yaitu: lama iklan di televisi atau besar iklan di majalah/tabloid dapat diperkecil.

Promosi below the line dan above the line (Promosi $360^{\circ}$ ) sebaiknya dijalankan secara bersamaan, sebab kedua promosi tersebut tidak dapat berjalan sendiri-sendiri. 


\section{DAFTAR PUSTAKA}

Aaker, David. A. Managing Brand Equity. New York: The Free Press, 1991.

Belch, George E. \& Michael A. Belch. Advertising And Promotion. Edisi 7. New York: McGraw Hill, 2007.

Brannan, Tom. Integrated Marketing Communications. Jakarta: PPM. (Penerjemah: Slamet), 2004.

Best, Roger. J. Market-Based Management. Edisi 4. USA: Pearson Interational, 2005.

David, Fred. R. Strategic Management. Edisi 12. USA: Pearson International Edition, 2009.

Hawkins, Del. I, et al. Consumer Behavior. Edisi 10. New York: McGraw Hill. 2007.

Kotler, P., \& Keller, K. L. Marketing Management. Edisi 13. USA: Pearson International Edition, 2009.

Malholtra, Naresh. K. Marketing Research. Edisi 5. USA: Pearson International Edition, 2007.

Walsh, Partric. Paul. Product Differentiation and Firm Size Distribution: An Application to Carbonated Soft Drink. Dublin: Trinity College, 2000.

Ziegler, Kelly. Industry Analysis: Soft Drink. Washington, DC: Center for Science in the Public Interest, 2006.

Am J Public Health, vol. 97, p. 667-675, 2007.

Analisis Pengaruh Media Iklan Terhadap Pengambilan Keputusan Membeli Air Minum Dalam Kemasan (M. Nasir Ibrahim, Jurnal Manajemen \& Bisnis Vol. 5, No. 9 Juni 2007).

Beverage World, global edition, April, 2009.

Food Industry Indonesia - 3rd Edition, Published by The Indonesian Business Data Centre (IBDC), 1997.

Management Perception of the Importance of Brand Awareness as an Indication of Advertising Effectiveness (Marketing Bulletin, 2003, 14, Article 2).

Media Scene, Volume 19, 2008.

Media Scene, Volume 20, 2009.

http://en.wikipedia.org/wiki/Soft_drink

http://ellachamelia-memories.blogspot.com/2009/11/ipal-industri-minuman-ringan.html

http://www.beveragedaily.com/Industry-Markets/Soft-drinks-are-hot-and-getting-hotter\#

http://www.nxtbook.com/nxtbooks/idealmedia/bw0409/index.php?startid=S1\#/30

http://www.wisegeek.com/what-is-root-beer.htm

http://www.essortment.com/all/historyrootbeer_rhnc.htm

http://www.ad-buying-secrets.com/daypart-advertising-rates.html

http://www.iptek.net.id/ind/?mnu=5

http://en.wikipedia.org/wiki/Human

http://www.biologyreference.com/La-Ma/Life-Cycle-Human.html

http://pengukuran-efektivitas-iklan-televisi-minuman-ringan-coca-cola-versi-\%E2\%80\%9Dcoke-untuksemua\%E2\%80\%

http://artikel-info-kesehatan.blogspot.com/2009/07/aspartam-sejenis-pemanis-buatan-yang.html

http://www.netmba.com

http://1000langkah.wordpress.com/2009/01/05/iklan-artis-endorser-bintang-iklan-pentingkah/

http://www.zenithinternational.com/market_industry_reports/report_detail.aspx?id=194 